Nation's Two Bodies

rethinking the idea of 'new' India and its other

Kaur, Ravinder

Published in:

Third World Quarterly

Publication date:

2012

Document version

Early version, also known as pre-print

Citation for published version (APA):

Kaur, R. (2012). Nation's Two Bodies: rethinking the idea of 'new' India and its other. Third World Quarterly, 33(4), 603-621. http://www.tandfonline.com/doi/pdf/10.1080/01436597.2012.657420 
This article was downloaded by: [109.186.95.5]

On: 06 May 2012, At: 04:42

Publisher: Routledge

Informa Ltd Registered in England and Wales Registered Number: 1072954 Registered office:

Mortimer House, 37-41 Mortimer Street, London W1T 3JH, UK

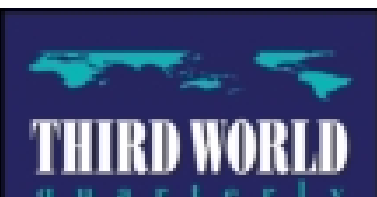

\section{Third World Quarterly}

Publication details, including instructions for authors and subscription information:

http://www.tandfonline.com/loi/ctwq20

\section{Nation's Two Bodies: rethinking the idea of 'new' India and its other}

Ravinder Kaur ${ }^{\text {a }}$

${ }^{a}$ Department of Cross-cultural and Regional Studies, University of

$\operatorname{Tin} 30$

Copenhagen, Denmark

Available online: 30 Apr 2012

To cite this article: Ravinder Kaur (2012): Nation's Two Bodies: rethinking the idea of 'new' India and its other, Third World Quarterly, 33:4, 603-621

To link to this article: http://dx.doi.org/10.1080/01436597.2012.657420

\section{PLEASE SCROLL DOWN FOR ARTICLE}

Full terms and conditions of use: http://www.tandfonline.com/page/terms-and-conditions

This article may be used for research, teaching, and private study purposes. Any substantial or systematic reproduction, redistribution, reselling, loan, sub-licensing, systematic supply, or distribution in any form to anyone is expressly forbidden.

The publisher does not give any warranty express or implied or make any representation that the contents will be complete or accurate or up to date. The accuracy of any instructions, formulae, and drug doses should be independently verified with primary sources. The publisher shall not be liable for any loss, actions, claims, proceedings, demand, or costs or damages whatsoever or howsoever caused arising directly or indirectly in connection with or arising out of the use of this material. 


\title{
Nation's Two Bodies: rethinking the idea of 'new' India and its other
}

\section{RAVINDER KAUR}

ABSTRACT The idea of a post-1990s re-formed India is shaped by an imaginary of a fractured body of the nation - a 'new' nation in tune with the neoliberal desires of a structurally adjusted world and the 'old' nation constitutive of superfluous matter in excess of that seductive world. This imaginary is not only etched in popular discourses but also in the policy-making apparatus engaged in the task of creating a global identity for India. Taking the Brand India initiative - promoted by the Indian state to produce positive images of the nation for global publicity - as a case study, this article argues that in this shift from nation building to nation branding, the very idea of prosperity and equity has now become first and foremost a matter of image. In this world of images, one can also witness how a competitive strategy to seek more corporate investments through concerted brand campaigns has redefined the relationship between the nation and corporations. While earlier it was the corporations which sought the endorsement and patronage of the sovereign, now it is sovereign nations which are seeking to become the most favoured investment destinations' that purvey global capital.

\author{
India. Right place, Right time. ${ }^{1}$ \\ There are two Indias in this country. \\ One India lives in the optimism of our hearts. \\ The other India lurks in the skepticism of our minds. ${ }^{2}$
}

When Tata Group's ambitious Nano car project was withdrawn amid violent protests in Singur in 2008, Suhel Seth, a Delhi-based managing partner of a strategic branding firm described it as 'a slap on the face of Brand India'. 3 This rather visible depiction of violent affront and vexation caused to India's new global face was spiked with a further warning: 'Which foreign company will want to come in when India's most respected group cannot set up industry in a state?'. The question was laden, at once, with a sense of palpable anxiety, provocation, and even foreboding that had become emblematic of

Ravinder Kaur is in the Department of Cross-cultural and Regional Studies, University of Copenhagen, Denmark.Email: rkaur@hum.ku.dk.

ISSN 0143-6597 print/ISSN 1360-2241 online/12/040603-19

(C) 2012 Southseries Inc., www.thirdworldquarterly.com

http://dx.doi.org/10.1080/01436597.2012.657420 
the current debates about the perceived obstructions to India's brand image in the world.

The violent protests could not have been more ill-timed as far as the Indian state and the corporations were concerned. The neoliberal economic reforms set in motion in the late 1980s were finally said to be bearing results-India was increasingly described as an assertive nation taking long economic strides to create a vast, prosperous middle class, attract unprecedented levels of foreign direct investment, and even boast of four Indians in the top 10 of the Forbes billionaire list. ${ }^{4}$ The state led efforts began in the mid-1990s to establish a viable and globally competitive corporate brand for the Indian nation. Brand India had a decade later gained world-wide recognition among multinational corporations as well as the rich industrialised nations as an attractive destination for investments. The global displays of a re-formed nation at the annual meetings of the World Economic Forum at Davos and the enticing images of 'Incredible India' campaigns had by now successfully iterated and circulated the idea of a market-friendly India. The sixtieth anniversary of India's independence had similarly served as an opportune moment to take stock of the past decades, through which the nation had arguably transformed from a Third World country mired in a Nehruvian vision of 'mixed economy' to a 'structurally adjusted' Asian economic giant which, together with China, was about to change the course of global history. 'India Rising' was now a popular subject adorning coveted magazine covers, newspaper features, documentaries, short films, vision papers and realigned foreign policy strategies all over the world. This new global discourse on India served an additional purpose of creating a stark contrast to its neighbour, Pakistan, with which it shared its genealogy as well as a protracted history of unresolved conflicts. It seemed that India's moment of celebration had finally arrived: a moment that just a generation ago was difficult to imagine outside the limits of desire.

At precisely this moment of alliance between the nation and corporation the violent unrest in Singur erupted to draw out in plain sight the unruly to reveal the two bodies of the nation: the nation of seductive brand images and its undesired shadows that stubbornly refuse to disappear from the global gaze. The notion of shadow, here, suggests the undesirable matter-the poor, the unbeautiful and the unruly - seemingly in excess of the neoliberal dreams of the Indian middle class. The question this article addresses is: how do images and their shadows produce the imaginary of 'new' India in the world of strategic brand making? And how is the carefully assembled world of images realised, circulated, subverted and even emptied out? Through a close reading of Brand India campaigns, I examine the visual production of new India through a range of advertising campaigns that seek to corporatise and commodify the imagined essence of the nation. Rather than read the nation's brand-making campaigns under the sign of state propaganda, I approach them not only as sites of visual communication, where seductive images invite and address the global public, but also as sites of interrogation, when the public gaze is turned back critically on the content, form and social space these images occupy. To this end, the article examines the modes of address 
visible in the recent Brand India campaigns and the visual and discursive ruptures that shape the historical imagination of new India.

\section{Shadow of images}

Two related theoretical concerns frame my argument. First, how the new relationship between the nation and corporation is shaped in an increasingly hyper-competitive environment where nations compete to gain the most favoured 'investment destination' status. The favoured mode of address is to 'dress up' the nation to make it more 'attractive' for potential investors through nation-branding campaigns that showcase the effects of structural adjustments, open access to markets, and less government regulation. In the past decades, we have witnessed how the traditional relationship between the nation and corporation has altered as the nation is transformed in the image of the corporation, and its legitimacy is contingent upon its ability to draw corporate patronage. ${ }^{5}$ What I show in this article is the intensification of this role reversal between the nation and corporation. Whereas it was once the corporation that sought patronage and endorsement as purveyor to the sovereign, now it is the nation that is revealed as purveyor to the global capital - as provider of raw material, cheap skilled labour and an unfettered access to open markets. This particular relationship is most visible in the world of advertising and nation branding, where national and corporate interests seem to be in full convergence.

Second, how does the social life framed within the visual surface of nationbranding campaigns interact with the life outside them? Or, put another way, what kind of relations bind the semiotics of the nation brand to the messy world of its materialisations? These questions have gained urgency in the past few years as glossy images contained within the frames of Brand India campaigns are routinely juxtaposed with the undesirable images -impromptu showcasing of extreme poverty, deprivation, farmer suicides, corruption, inefficiency, unruly mass protests, and violent state repression against demands for autonomy - of the nation. What meanings does this counterimagery render to the nation-branding campaigns? And how do brand consultants and policy makers eager to build a positive image of the nation deal with this shadowy flow of unregulated images in a liberal democratic setting? As we will see, these questions and dilemmas are inextricably linked to the discourse of 'two nations' that frequently appears in the public debate. But before we get ahead of ourselves, a brief account of the idea of image makeover of the nation-form is in order.

A defining aspect of neoliberal economic restructuring over the past few decades has been the remaking of the nation-form in the image of the corporation-Nationality, Inc - complete with its own trademark and a brand image. The shift marks the move from the ideas and practices of nation building to those of nation branding, which is often suggested as the attainment of a higher and more complete form of nationhood appropriate to the era of globalisation. While this unabashed public alliance of the 
nation-state and corporation is not entirely a new phenomenon, the relationship has become more transparent as the state increasingly becomes a manager of capital. ${ }^{6}$ The nation and its image, in this species of relationship, become a rich resource that can be commodified to generate and attract capital through tourism and investment. Not surprisingly, a number of nations, especially those decolonised in the mid-twentieth century and sometimes labelled 'emerging powers', have invested in image makeovers to alter the world's perceptions. ${ }^{\top}$ While the discourse of development lay at the core of the nation-building attempts of the post-Independence years, the nation-branding exercise is inextricably connected to the magical world of seductive images. ${ }^{8}$ One can frequently witness, for example, the national essence of Malaysia, Qatar, South Africa, Croatia, Brazil and India in 'an avalanche of images' circulated on international media that evokes cultural difference within an aesthetic frame informed by Western sensibilities. ${ }^{9}$

The most characteristic sign of identification of 'new' India is its recently made-up face-Brand India-which has been specifically designed for display in the outside world. ${ }^{10}$ Its distinctive feature, separating it from other similar initiatives such as India Shining, is its almost invisible visibility: Brand India barely figures in the Indian public imagination, even while it successfully creates spectacular displays of India globally. In a way Brand India has emerged as a discreet image machine-limited to the world of policy makers and advertising professionals - that produces, translates and propels the Indian nation into the global orbit of big businesses, international financial institutions and leaders of rich nations without revealing itself in the process.

The India Brand Equity Foundation (IBEF) was created under the aegis of the Ministry of Commerce in 1996 as part of liberal reforms to promote 'Made in India' brands around the world. ${ }^{11}$ This lagging project was revived in late 2002 by the BJP-led government, although with a redefined task - not only to showcase Indian brands abroad but to transform India itself into a corporate brand. The official brief was to 'celebrate India' as the 'destination of ideas and opportunities' in order to bring in foreign direct investment (FDI) as well as to invigorate tourism. ${ }^{12}$ By 2004 Brand India was set to 'build positive economic perceptions of India globally'. In 2011 the purpose was further developed 'to portray the distinctive qualities of all things Indian and...the dynamism to build an enduring reputation [of India] in the competitive global arena'. A Delhi-based advertising agency specialising in place branding was recruited to create a distinctive logo, a slogan and a 'business kit' to be presented through glossy campaigns in international print and electronic media. The new initiative not only formalised the corporate approach to governing the nation, it also confirmed the alias by which the nation is known in the corporate world-India Inc - an entity consequently governed by a CEO rather than a political representative. ${ }^{13}$

Brand India offers a synoptic vision into this new historical imagination of India - a young nation seeking to find its place in the global scheme of things. It is conceptualised, in branding terms, both as a generic mother brand that brings together various initiatives on tourism and businesses, as well as the 
public face of a government agency, IBEF. While Incredible India has by now become a well recognised brand that sells India to tourists around the world, corporate branding is done through a more strategically targeted series of campaigns, such as 'India Everywhere', 'India Now', 'Resilient India' and 'India Marches Ahead', assembled under the theme of 'India-fastest growing free market democracy'. Both the initiatives are aimed at the outside to attract global attention; although the former is a mass campaign visible in international media and global publics, the latter is directed more discreetly at leaders of states and corporations seeking profitable alliances.

In the world of strategic image makers, creating brand images for a young nation is seen as a necessary tool to close gaps between the perception and reality of the nation. ${ }^{14}$ According to a nation branding consultant, "the running of countries is no different from the running of a large company' and 'a nation that does not engage in proactive branding runs the risk of being positioned anyway by its competitor to the competitor's advantage'. ${ }^{15}$ While the project of constructing a national imaginary is nothing new and is considered integral to the developmental project of nation building, this reasoning about nation branding signifies a momentous shift. ${ }^{16}$ The old imperative to build national identity to secure internal cohesion and unity within the 'imagined community' is now supplemented by the logic of external competition within the 'family of nations'. In fact, nation branding is a globally recognised practice which Simon Anholt, a nation-branding expert, describes as "national identity in the service of enhanced competitiveness'. ${ }^{17}$ This advice to brand nations is considered particularly applicable to 'young nations' which 'are in a unique position to brand themselves because they are in an early stage of development'. ${ }^{18}$

Two significant assumptions underpin this belief. First, the nations thought to be in particular need of a globally recognisable brand image are presumed to be 'young', that is, inexperienced, immature, unpredictable, and often without a sufficiently 'proper' history. This description of youthful nations is not only reserved for the postcolonies in Asia, Africa and Latin America, but also applied to post-socialist nations that crossed over to a liberal market economy in late capitalism. Compared with mature nations across the North Atlantic, the nations in the global South are imagined as beginners who have merely tiptoed out of the 'waiting room of history'. In other words, their history proper is only seen as beginning with market reforms. Second, the trope of 'reality' - the transcendent and radiant domain produced by the 'gains' of free market forces - seeks to surface the subterranean transformations within neoliberal societies. In this new landscape of reality the nation's complex histories are erased only to be revealed as an archive of 'facts' and 'events' that can be teleologically rearranged to construct a proper history. The images of familiar objects, ideas, people and places appear in this new narrative, yet they are connected in a wholly new sequence that might bear little resemblance to the original.

The challenge, then, is how to engage with these nation-brand images beyond the registers of 'reality' and 'fiction'. While nation-branding these days is increasingly offered as a quick-fix solution to enhance, repair and 
restore a nation's image in the eyes of the world, it is frequently dismissed as an empty gesture, an imaginary nation that is nothing other than an image. However, as Ranciere reminds us, if there is nothing other than the image, 'the very notion of the image becomes devoid of content'. ${ }^{19}$ This means taking the image seriously to engage with its paradoxical being and not succumbing to the temptation of looking for meanings confined within the visual frame. ${ }^{20}$ Instead we may turn our attention to the 'work of imagination' that produces the visual frame itself, its modes of address, paths of circulation and the wider social setting within which the surfaces of display are produced. ${ }^{21}$ To this end, the specific modes of address deployed by Brand India campaigns offer an insight into the imagination of 'new' India within a global publicity where familiar meanings are displaced and signs reverted in order to create a new nation. This article foregrounds the social life inside and outside brand images and the ways in which they are shaped under a critical global gaze.

\section{The image machine}

While Brand India was initiated in the mid-1990s, it was not until roughly a decade later that it became an image machine for the nation-manufacturing and circulating worldwide alluring images of India and the discourse of 'global Indian-ness'. The biggest challenge has been to sort out what to publicise and which messy realities to deflect attention away from. One might ask, then, what secreted logics of the new nation are articulated in the global publicity, and how? The function of these forms in singularity and collectivity is to seek out, empty and remould the essence of the Indian nation in harmony with global free markets. It is not a coincidence that one of the first major spectacles organised to unveil the Brand India campaign was in 2006 at the annual meeting of the World Economic Forum in Davos. The choice of location itself is instructive. The annual meeting has been bringing together more than 1000 top-earning businesses in the world, heads of states and influential policy makers for the past 40 years. ${ }^{22}$ According to the Forum's own description, it is a critical platform that has introduced 'emerging economies such as China and India to the international community'. ${ }^{23}$ It is by now a well known global venue where businesses network and gain easy access to policy-makers in various nations. Similarly nations in search of investments are likely to find businesses eager to expand into new markets in this setting. Thus, for 'emerging powers', Davos is said to be an obvious location where the nation must be displayed before an elite audience popularly described as 'world leaders' in business, government, academia and civil society.

The advertising professionals entrusted with the Brand India project in the mid-2000s were given a seemingly simple brief: to create a new look for India that would reflect its post-economic reform achievements and consolidate it as a prime investment destination. ${ }^{24}$ The task was more complex than it initially seemed, as it meant severing ties with the 'old' India, as I was told frequently, without letting go of the essence of its unique cultural brand-value 


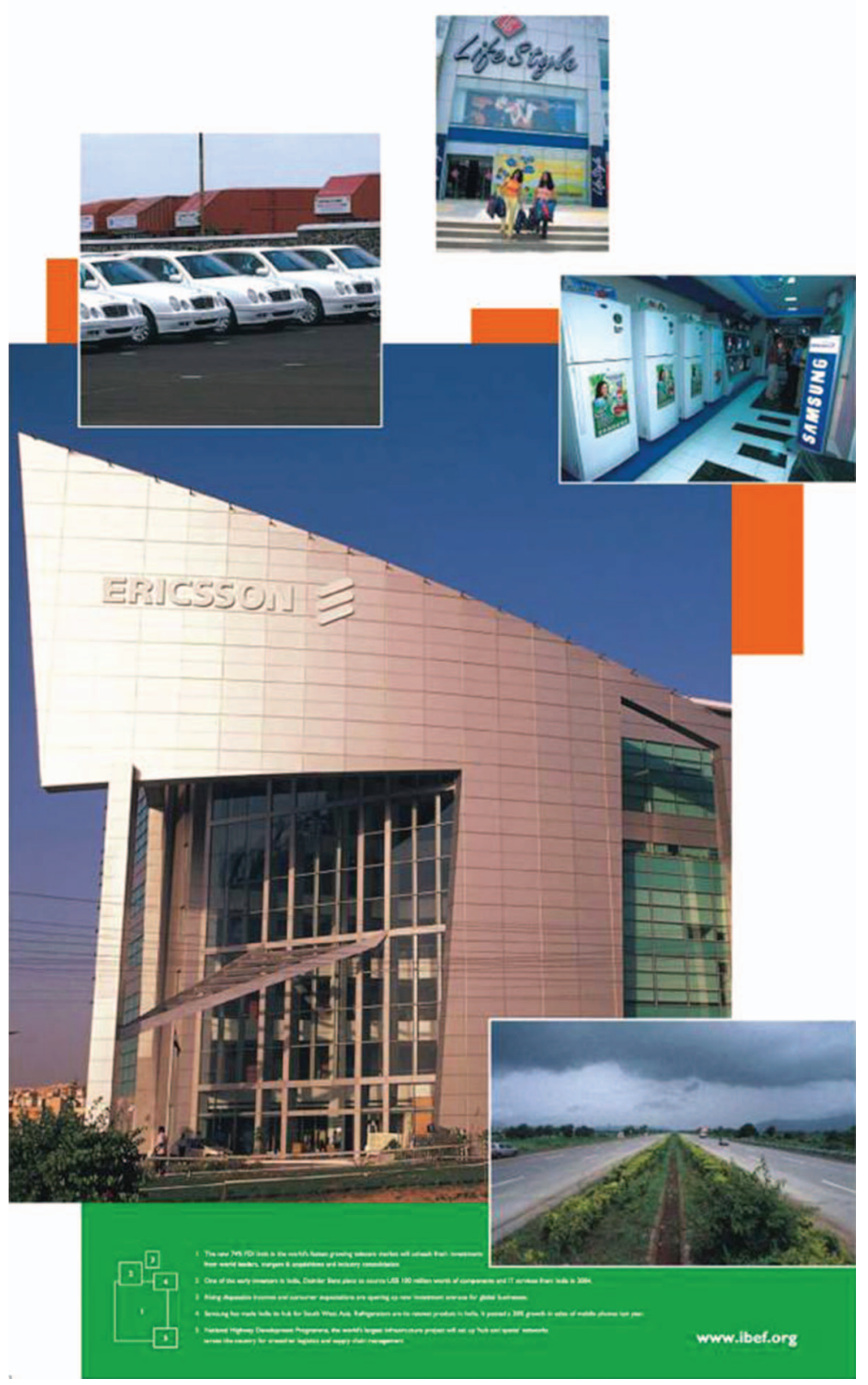

FiguRE 1. India: Best country to be an investor in. Source: Courtesy of India Brand Equity Foundation. 
built over centuries. The 'new' India seemingly was to be based on a combination of bits of 'old' India surgically removed from its larger body, so that it could fit the growing global narrative of a re-formed nation. In other words, the task was to create the look of an ancient civilisation turned global power ready to conduct business with the world. I describe three key stages in this process of visual rearrangement of the nation's body-disrupting the familiar, the 'new' familiar, and finally corporate endorsements of the new nation - which seek to visually transform the nation into an attractive partner for global businesses.

The first set of images - what I call disrupting the familiar-produced to attract the world's attention at Davos was a short film called India Now. The film was part of a digital package distributed to more than 2000 delegates in information CDs and Ipods, and was screened at major public venues too. The idea was to invoke objects, places, people that are instantly associated with India and then visually break that connection in order to form new associations. The $1 \frac{1}{2}$-minute-long film begins with a stream of white, green and saffron shades that come together to form a digital inscription-India: fastest growing free market democracy. The subsequent visuals are composed of a series of facts and figures about India's liberalised economy and democratic foundations in order to support the main theme. The visuals are layered with moving images tracing familiar ideas, objects, people and places across different temporalities associated with the popular imagination of India, and are superimposed with simple statements of facts that testify to the claims of a robust economy and democratic state. At first, the choice of images signifying India seems eclectic and even random: Taj Mahal, the national flag, Jawaharlal Nehru making a historic speech, bindis, bangles, elephants interwoven with images of shiny computers, mobile phones, wires, headsets, smooth highways, high-rise buildings, cars and hi-tech machinery. These objects and places are the background against which men and women in white coats, headsets and microphones are seen deliberating or posing to display the rational scientific temperament. A visual scheme slowly begins to emerge from what initially seemed the random order and selection of images.

The array contains some iconic images of the essential cultural and historical symbols, interwoven with new images depicting universally identifiable symbols of techno modernity. The colour scheme sets off one set of images against another-black and white to suggest the foundational aspects of a 'young' India and vibrant colours to indicate the global translation of the nation. The images appear in rapid succession one after another, so much so that the viewer is eventually unable to distinguish one from another after a while - the familiar and the unfamiliar; faded black and white shots from colourful visuals. In one sequence, a well recognised object such as the national flag traces associations with another familiar object, the Taj Mahal, and then disappears instantly to make way for new objects - a glossy highrise building and shiny car on a highway. The technique is to seamlessly weave seemingly different objects and themes together, and precisely in doing so to disconnect the old from the new in such a way that a wholly new 
narrative is produced. The familiar is invoked only to have the sign reverted and displaced with new associations in order to articulate new meanings. The rapid chain of quickly shifting images brings the iconic images to the surface and places them in a new frame together with hitherto unrelated objects. Thus the Taj Mahal is no longer isolated from IT professionals in Bangalore; likewise the India associated with natural, animal themes - elephants and tigers - is now framed together with visions of industrial development. In this way the cultural and historical images are displaced and reclaimed from the older contexts of colonial subjugation and Third World underdevelopment. This chain of new associations forms the rough outline within which the narrative of a reformed nation can be witnessed.

The second set of images constitutes the 'new familiar' - an identity of the nation that grows out of a gradual erasure of the old sign system. In a 2007 campaign called 'India: Right place, Right time', a series of elongated, vertical digital posters appear in bright fluorescent colours that carry an image and new facts about India. As the title suggests, the campaign was to invite investors to come and partake in the vast market that is India. The late 2000s were seen as the ripe moment for investment when Western markets had just begun talking of a property bubble and investors had started looking for alternative markets in which to invest. The re-formed India represented the right place and right time for investment. The posters, each carrying a depiction of a globalised Indian market scene, were displayed in Davos and other major cities of the world and were available for digital download as well.

One of the posters contains a visual of a shoe shop, probably located in a shopping mall. The counter is lit by halogen lights fitted in a lowered semicircular false ceiling which reflect brightly upon the marble floor. A customer dressed in salwar kameez is seen gazing at a shoe, while other customers and shop attendants participate in the labour of consumption. The lower part of the poster is a rich magenta shade with two words inscribed in bold- Super Market. A text in smaller print follows to reiterate India's status as a large emerging consumer market. The posters, rather than relying upon recognisable symbols within the image, are framed as panels of colourful saris, with borders decorated with a phool-butti design. The coloured background is also composed of the same flowered motif that runs across all the posters. The images in this series of digital posters suggest modernity symbolised by objects representing high technology, computers, walls of blinking computer screens, aeroplanes, metro, bridges, cars and mobile phones. Yet they are framed discreetly within the edges of sari borderssuggesting Indian-ness as the broader frame- -within which a new sign system is revealed to facilitate the public encounter with the new relationship between hi-tech objects and India. Unlike in the earlier images, which are characterised by bold use of well known signs of Indian-ness, the latter images are distinguished by a more discreet use of objects and patterns signifying India. In fact, practices and objects termed as modern appear under the sign of India as suggested by the sari borders which frame the activity of consumption. 
RAVINDER KAUR
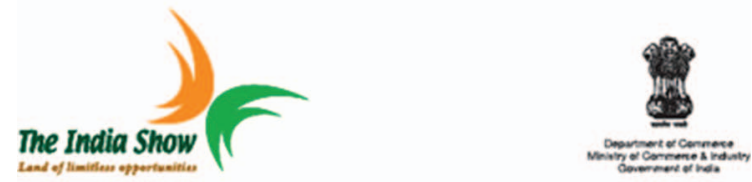

\section{THE RESEARCH HUB}

The R\&D programmes of over 100 Fortune

500 companies are powered from India
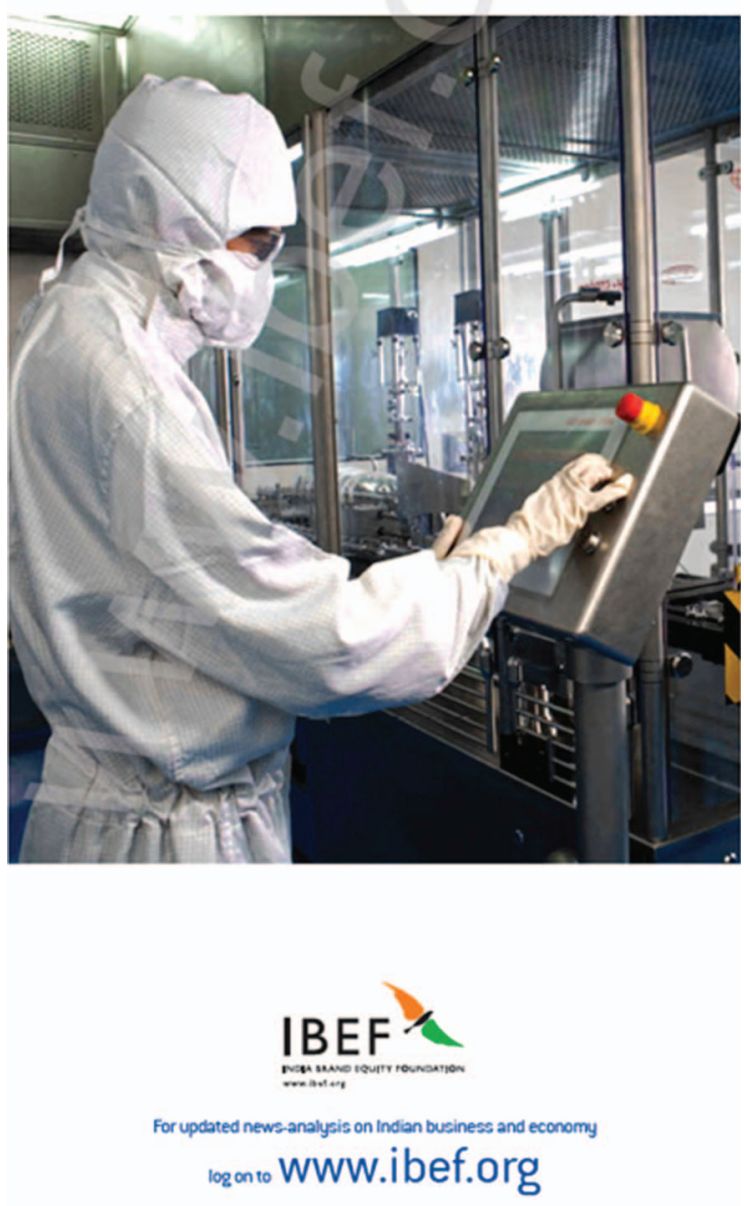

FIGURE 2. Branding India as a hub of scientific knowledge. Source: Courtesy of India Brand Equity Foundation.

612 
RETHINKING THE IDEA OF 'NEW' INDIA AND ITS OTHER

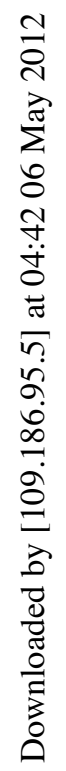

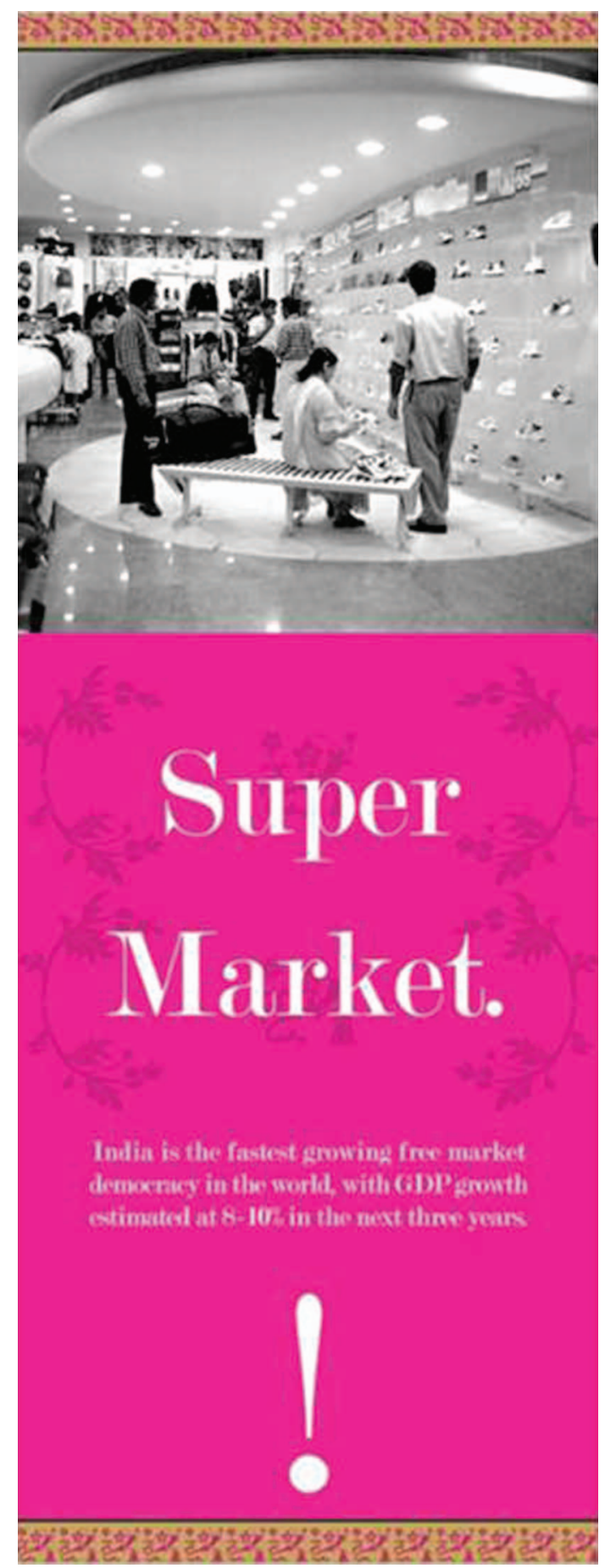

FIGURE 3. Supermarket.

Source: Courtesy of India Brand Equity Foundation. 
The most important set of images, however, is the third one, which reveals a new orbit of connections that bring objects and people not directly connected together under the sign of India. This form of nation branding based on corporate endorsement not only visually discloses what is already well known - the collapsed boundaries between the domain of politics and the domain of economy - in addition, it tells us the extent of role reversal between the sovereign and the corporation. The official website of IBEF is designed so as to show the attractiveness of the nation to investors through testimonies and endorsements from big businesses already in India or about to be there.

The following is an example of glossily designed corporate frames of the nation. A slideshow of snapshots begins with an image of diamond jewellery displayed on rich, red velvet cloth, suggesting old wealth and luxury. The image disappears to make way for a text which simply states, 'India is a growing market for luxury'. This text is an endorsement offered by Julius Kruta, the 'head of Tradition' at Bugatti Automobiles, the car manufacturer for the wealthiest in the world. The brand Bugatti is associated with the worlds' fastest and the most expensive car, with a base price tag of $€ 1.1$ million that can speed up to $407 \mathrm{kmph}$ on smooth roads. Since 2010 Bugatti has been available in India, which the company sees as an emerging market for luxury goods. In this brief slideshow, images and voices from outside the nation are drawn to create a new grammar of the image. Instead of direct links, various, unrelated elements such as diamonds, red velvet background are sequenced together with a factual statement about India's growing luxury market articulated by a luxury car maker. The embedded meanings of the objects in the image and the text are transferred to India as they are enclosed within the same image frame. This transference is made as an undisputed matter of fact, suggesting that different objects do share meaning. Within this image frame, the relationship between the objects becomes apparent as one complements the other and even turns into a substitute for the other.

While this is a routine advertising strategy to draw alliances and connections where none may exist, we are witnessing something novel in this sequence of images: a commodity (desirable foreign car) manufacturer endorsing the nation. This is the reversal of the previous relationship between the nation-state and the corporation. One usual practice which bound the two was the grant of a royal warrant to the manufacturer or merchant of commodities consumed by the sovereign. The favoured company was then allowed to use the logo and symbol inscribed in the coat of arms on its product-bestowing the prestige value enjoyed by the sovereign on the corporation. Such a favoured corporation joined the ranks of the 'purveyors to the royal court' and could advertise their products as such. The company and the commodities thus patronised came to be seen as quality products fit for the sovereign, and thus signified a higher exchange value than did similar products. In the case of Brand India it is the corporations which are aggressively sought by the nation in order to seek patronage and the use of their logos. The success of the nation is predicated upon its ability to attract 
big corporations so as to guarantee its enhanced value in the global market. Thus, in a role reversal, the nation is now revealed as the purveyor to global capital.

This mode of address is designed for global publicity where corporations are enclosed together with the sign of India within the same visual frame. As corporations add their logos and voices to make a pitch for the nation, this new alliance inaugurates India into expansive markets, along with other similarly re-formed nations. Here, cultural-historical facts about India become useful props that help the nation differentiate itself from other nations seeking the corporation's attention. Thus, a new imaginary of the nation - composed of carefully assembled images - that is at once global as well as characteristic of its vernacular particularities is made palpable.

\section{India vs India}

The convergence of the corporate interest with that of the nation visible in the brand initiatives is only part of the story. The other part is the contestation and subversion from within the nation which disrupts the smooth imagery. While the Indian state is heavily invested in the creation of the country's global identity on the one hand, it is also beset by a variety of scandals said to be corroding the inviting visage of Brand India on the other. The anxiety over the negative publicity has also set in motion a form of public and collective introspection. The question at the heart of these sometimes intimate and candid reflections is: why does India keep on failing to realise its full potential and destiny as a great power? This question in different modes and forms has been the subject of innumerable newspaper articles, television discussions, internet blogs and policy debates in recent years. These concerns are becoming especially palpable when framed in the context of China's stupendous economic growth in relation to which India lags far behind. A common discourse shaping various debates is that of a ruptured nation constantly at war with itself. While a number of dichotomies are usually employed to describe the bodily rupture - rural/urban; rich/poor; cosmopolitan/vernacular - it is the contrast between the 'old' and 'new' India that has come to define the current post-reform schism. This theme became particularly popular during the Commonwealth Games debacle, when India's image as a global player was said to be in the course of unravelling.

A note on the corrosive scandals contaminating the image of new India would be in order here. When the city of Delhi became host to the 2010 Commonwealth Games (CWG), it was expected to follow the Chinese precedent of hosting flawless Olympics Games in Beijing two years earlier. That spectacular cultural extravaganza was not merely a mega-gathering of sportspeople, rather its carefully choreographed show was read worldwide as a memorable debut of China as a great power on the global stage. The CWG, though less prominent in scale, nevertheless offered an international backdrop against which India could showcase its post-reform achievements and build its global brand of world-class road infrastructure, airports, public 
transport facilities, fresh modes of governance based on public-private partnerships, and well behaved citizens who had been especially asked to politely observe the rules during the Games period. In short, Delhi was to emerge as a world-class city on par with other mega-cities in the rich industrialised world. However, these ambitions were dented a few months before the Games were to begin as the Commonwealth Federation expressed its doubts about the readiness of the sports infrastructure. In the following weeks the images that began circulating within global media were in deep contrast to the image world of Brand India. ${ }^{25}$ Not only were the sporting and housing facilities for the athletes found to be in a semi-finished state, they were declared 'unfit for human habitation' as images of filth and animal excreta in the apartments were circulated widely around the world. ${ }^{26}$ While the games officials tried to explain this criticism as 'differences in standards of our hygiene from theirs', ${ }^{27}$ the strategic brand image-makers interpreted this visible depiction of shame to India's new global face as 'essentially as saying that we are not world class yet, we are still a third world country...we are not your level yet'. ${ }^{28}$ In short, Brand India was said to be in jeopardy and at the risk of unravelling precisely at the moment when the global gaze was upon India.

If the hope of the Games officials and the Delhi state government was that the moment of shame would disappear once the actual Games had been successfully concluded, then that was clearly undone in the avalanche of bad publicity that followed. On the one hand, the social activists were drawing attention to the exploitation of labour and poor conditions under which the CWG construction workers lived and worked, on the other hand Games officials had come under scrutiny for taking bribes and for corrupt practices in handing out building contracts. The poor quality of construction work was clearly revealed when an overhead bridge collapsed days before the Games inauguration, while part of the ceiling in a newly built stadium fell down on the spectators. In the subsequent weeks allegations of corruption had compounded to an extent that the CWG scandal, estimated at $£ 2.5$ billion, came to be regarded as one of the largest ever financial scams in India. The image of a corrupt India governed by inefficient bureaucrats was further entrenched in 2011 when corruption became a rallying ground for mass mobilisation following revelations of financial embezzlement worth scores of billions. The domain of the political was now defined by spectacular scandals and the failure of an unworthy political class to govern the nation efficiently.

It is against this background that the idea of a split nation gained currency within the public domain. The most explicit description of this idea was articulated by a well-known weekly newspaper columnist, Vir Sanghvi, as the negative news coverage of the Games began gathering ground. In a widely circulated article called 'Old India vs new India', the author voiced public anger and frustration at the national shame that had to be endured because of corrupt, incompetent Games officials. The crux of the analysis was pegged around the essential and unbridgeable distinctions between the old and the new. The 'old' was described as 'corrupt, slothful, incompetent, chaotic, unconcerned with the pursuit of excellence, and unwilling to benchmark 
global standards', whereas the 'new' was the emerging superpower 'that can do things to global standards, whose competences and intelligence are highly regarded all over the world, an India where people work hard, where there are high levels of accountability and where commitments are treated as sacred'. Clearly the old/new distinction, here, does not pertain to time and space differences. Rather it reveals two distinct nations under the sign of India as fetishised embodiment of opposing personal attributes and a web of associations. In fact, the two figurative imaginaries of India seem to have become autonomous subjects in their own right, displaying affective relationships with other subjects (state, investors and citizens) directly. The personalisation of the nation easily translates to a larger public the current antagonistic discourse of a split body where each part appears as a sovereign subject capable of independent action and designs for the future. It is hardly surprising, then, that the failure of the Games organisers to create an enviable spectacle like China's was explained as 'old India having failed the new India' which had made the nation 'in eyes of the world... a laughing stock'. ${ }^{29}$ In short, the limits to progress, development and transformation of the nation into a great power commanding awe and respect were seen as marked from within. And unless this internal saboteur was controlled, India's ambitions and potential would never be fully realised.

The spectre of a ruptured nation circulates a well rehearsed logic of internal conflict and the underlying threat of subversion. In a 2007 television campaign, 'India Poised', created to mark India's sixtieth Independence anniversary, the idea of a ruptured nation's body was rendered poetically within the popular domain. The short, black and white video called India vs India featured the Bollywood superstar Amitabh Bachan articulating the idea of two nations. The video - a mixture of optimism, hope and anxiety-begins with the assumption that India is poised at a 'rarely ever moment' when 'history is turning its page. . . and a pulsating, dynamic new India is emerging'. Yet the historic moment is seen as fragile, and its precariousness accentuated by a fractured body of the nation where "one India is straining at the leash, eager to spring forth and live up to all the adjectives the world has been recently showering upon us; the other India is the leash'. ${ }^{30}$ The contrast is clearly laid out to demarcate the new nation imagined and realised in conjunction with the world from its isolated other that keeps on holding it back. The idea of a schismatic India that is out of synch with itself as well as the world, and therefore unable to mobilise its full resources to reach its natural destiny of world leader is a worrisome theme frequently voiced in the media. The fear of alienating investors, tourists and influential global opinion makers from Brand India is what informs the discourse of a split nation.

This sense of urgency can be witnessed in the domain of politics too, as was visible in the recent anti-corruption mobilisation. While ordinary citizens were mobilised around the 'plight' of the common man by a social activist turned protest leader, Anna Hazare, a different kind of rationale had spurred corporate actors into activism to eradicate corruption and 'governance deficit' in public life. At the heart of this corporate activism was the fear that 
Brand India was being damaged beyond repair. Consider the following: at the height of the CWG scandal the Federation of Indian Chambers of Commerce and Industry (FICCI) issued a statement calling for probity in governance in order 'to preserve India's robust image and keep the growth story intact'. ${ }^{31}$ This was followed by an open letter by 14 prominent individuals - corporate leaders, reform-minded economists and bureaucrats assembled together under the sign of 'citizen'-who identified corruption as the 'biggest issue corroding the fabric of our nation'. The recommendation of the group was to address the 'governance deficit' that had permeated every level of state institutions, and to restore the self-confidence of Indians in themselves and in the Indian state. ${ }^{32}$ The biggest support to fight corruption came from the corporate sector too. Corporate leaders expressed their support publicly, proclaiming that 'We completely support Hazare in his fight against corruption which has been denting India' ${ }^{33}$ The fear of losing India's place as an attractive investment destination has been at the heart of this corporate mobilisation on the one hand, and of the government's acquiescence to the broad demands for an anti-corruption legislation on the other. This anxiety of alienating corporations was visible in a recent controversy over a court case involving the largest financial scandal in India yet. The Minister of Law, Salman Khurshid, berated the Supreme Court for not granting bail to businessmen accused in the $2 \mathrm{G}$ spectrum scam. His matter of fact question 'If you lock up top businessmen, will investment come?' voiced concerns over threats to the pace of economic growth and investment in the nation. ${ }^{34}$ The logic of corporate patronage and investment in the nation has clearly become a matter of common sense to the extent that even the domain of law is deemed open for rearrangement so as to create exceptional spaces within the legal framework.

\section{Intimate alterity}

The idea of India conceived by the makers of postcolonial India was essentially a modernist project built on the embers of a fading empire and faced with the task of levelling geographies of unevenness within. The emphasis was on the 'idea of concrete' as Sunil Khilnani has memorably described it -initiating massive construction projects of dams, industries, cities and public works - on the one hand and, on the other, creating the institutional framework of democracy that has by now become one of the most defining characteristics of India. ${ }^{35}$ Through a variety of developmental interventions the state had hoped to address the questions of poverty, illiteracy, social inequity and overpopulation at different points in history in order to 'uplift' the masses lagging behind. This unfinished project has reappeared in post-reform India in new formations particularly visible in the world of images. The most characteristic feature of this new form is that the modernist project of development itself has become first and foremost a matter of image. The strategy of the Indian state is clearly no longer limited to the 'concrete', but has moved to the plane of image making, where the production and projection of images of a prosperous nation becomes as 
imperative a task as the creation of a prosperous nation itself. This shift is a reminder of what Baudrillard described as the hyperreal-the making of the real without origin or reality - that has become the hallmark of contemporary postmodernist sensibilities. ${ }^{36}$ In fact, in initiatives such as Brand India, we witness the relationship between the image and the real in reverse. It is not the real that precedes the image, rather it is the image that precedes the real. The tensions in such a project are inevitable, as we have seen the past few years.

The abstract world of images created in campaigns such as Brand India is probably more akin to what WJT Mitchell describes as the drawing of desires - perhaps even a model of the ideal - conjured to attract investors and wealthy tourists to engage with India. ${ }^{37}$ Once such an abstract model of an investor-friendly nation populated with a multitude of prosperous consumers and cheap skillful labour is created, the project becomes something else altogether-to make the real coincide with the model. This is where we witness the ruptures and tensions as policy makers attempt to superimpose the social life inside the frame on the social life outside of the image. Since the economic restructuring the major push has been to introduce an ever greater degree of reforms that will enable access to markets as well as resources. The recent political mobilisation against FDI in the retail sector and conflict over special economic zones in West Bengal are examples of incongruity between the image and the real. While the state is committed to the creation of cheerful consumers - as seen in the images of Brand India - on the one hand, and the creation of an investor-friendly environment on the other, political society mobilises itself to create a world that is at odds, sometimes violently so, with the image conjured by the neoliberal state. The trope of two nations, often invoked as a lamentation, thus captures precisely this tension between a nation that is in harmony with the markets, and its other, which continues to resist the same. It also invokes the most intimate form of otherness, a part of oneself that nevertheless remains inaccessible and resistant. It is here that the magical sign system of the hyperreal also breaks down, revealing not only the rupture in the image, but also the ruins and shreds left behind in the violent shift to free markets.

\section{Acknowledgements}

I remain deeply thankful to Aniket Alam, Ananya Jahanara Kabir and Srirupa Roy for providing critical readings of this article. The article has benefitted from discussions at the 2010 Asian Dynamics Initiative workshop 'Governing Difference', University of Copenhagen as well as South Asia History Seminars 2011 at SOAS, London. I wish I knew how to include more of the good ideas generated in these conversations.

\section{Notes}

1 Brand India campaign, 'Right Place, Right time', 2007, India Brand Equity Foundation, at www. ibef.org 


\section{RAVINDER KAUR}

2 India vs India, 'India Poised' campaign 2007, Times of India Group, at http://www.youtube.com/ watch?v=wP-TwHwLc98, accessed 15 December 2011.

3 'Protests force Tata to stop building car plant', New York Times, 2 September 2008; and 'Singur is a slap on the face of Brand India', Indian Express, 3 September 2008.

4 'India dominates Billionaires' List', Wall Street Journal, 6 March 2008, at www.blogs.wsj.com/wealth/ 2008/03/06/india-dominates-billionaires-list/, accessed 15 December 2011.

5 John Comaroff \& Jean Comaroff, Ethnicity, Inc, Chicago, IL: Chicago University Press, 2009.

6 For a detailed account of corporate activity under colonial rule, see R Birla, Stages of Capital: Law, Culture and Market Governance in Late Colonial India, Durham, NC: Duke University Press, 2009.

7 The idea of emerging powers is explored in C Jaffrelot (ed), The Emerging States: The Well Spring of a New World Order, New York: Columbia University Press, 2009.

8 See P Chatterjee, Nationalist Thought and the Colonial World: A Derivative Discourse, London: Zed Books, 1986; and D Ludden, 'India's development regime', in N Dirks (ed), Colonialism and Culture, Ann Arbor, MI: Michigan University Press, 1992, pp 247-288.

9 D Gaonkar, 'An avalanche of images', Public Culture, 22(2), 2010, pp 217-222.

10 William Mazarella describes brands as conceptual extensions of trademark that assert legal ownership of identity through logos and advertising images. However, Brand India does not make any legal claim towards ownership of India; rather it appears mainly as a marketing discourse. W Mazarella, Shoveling Smoke: Advertising and Globalization in Contemporary India, Durham, NC: Duke University Press, 2003, pp 185-187.

11 For an account of the shift towards brand making in newly re-formed India, see A Rajagopal, 'Thinking through emerging markets: brand logics and the cultural forms of political society in India', Social Text, 17(3), 1999, pp 131-149.

12 'Towards creating Brand India', Financial Express, 15 February 2003.

13 Manmohan Singh is popularly and complimentarily called the CEO of India Inc, a shift that is meant to mark the market friendliness of the nation. See, for example, the recently published portrait of the prime minister by A Ahuja (ed), Manmohan Singh: CEO, India Inc, Delhi: Pentagon Press, 2009.

14 Y Johnston, 'Developing Brand South Africa', in K Dinnie (ed), Nation Branding: Concepts, Issues, Practices, Oxford: Butterworth-Heinemann, 2008, p 5.

15 F Gilmore, 'A country - can it be repositioned? Spain - the success story of country branding', Journal of Brand Management, 9(4-5), 2002, p 283.

16 See S Roy, Beyond Belief: India and the Politics of Postcolonial Nationalism, Delhi: Permanent Black, 2007.

17 'Problem with your country's image? Mr Anholt can help', Guardian, 11 November 2006.

18 Gilmore, 'A country - can it be repositioned?', p 283

$19 \mathrm{~J}$ Ranciere, The Future of the Image, London: Verso, 2009, p 1.

20 WJT Mitchell, What do Pictures Want? The Lives and Loves of Images, Chicago, IL: Chicago University Press, 2005, pp 28-56.

21 A Appadurai, Modernity at Large: Cultural Dimensions of Globalisation, Minneapolis, MN: Minnesota University Press, 1999.

22 The annual meeting is an exclusive by 'invitation only' assembly of big businesses eager to network and influence policy makers. The paid membership is open to companies with an average turnover of $\$ 5$ billion. See www.weforum.org/members, accessed 15 December 2011.

23 'A partner in shaping history: the first forty years 1971-2010', Web Economic Forum, Geneva, 2009.

24 Interview with Amit Shahi, Creative Director of Ideaswork, a Delhi-based advertising agency specialising in place branding, 15 October 2010.

25 CNBC-TV18 'CWG mess and Brand India', at http://www.youtube.com/watch?v=3XE2WPzM-sA\& feature $=$ related, accessed 5 December 2011

26 'Commonwealth Games village is "unfit for human habitation", Guardian, 21 September 2010, at http://www.guardian.co.uk/sport/2010/sep/21/commonwealth-games-unfit-human-habitation, accessed 5 December 2011.

27 L Bhanot, Secretary, Commonwealth Games Organising Committee, comments in 'Games village world class', 21 September 2010, NDTV news reportage, at http://www.ndtv.com/video/player/news/ games-village-world-class-lalit-bhanot/164966, accessed 15 December 2011.

28 S Desai, CEO, Future Brands, 'Can India be found among the rubble?', CNBC-TV18 reportage and discussion, 18 October 2010.

29 V Singhvi, 'Old India has failed new India again', Hindustan Times, 25 September 2010. A longer version of the article is 'Old India vs new India', available at www.virsanghvi.com/CounterPointArticleDetail.aspx?ID=552, accessed 15 December 2011.

30 India Poised campaign.

31 'FICCI fears corruption will damage Brand India', The Hindu, 14 December 2010. 
RETHINKING THE IDEA OF 'NEW' INDIA AND ITS OTHER

32 'An open letter to our leaders', Hindustan Times, 17 January 2011

33 'Corporate India says it backs Anna Hazare', Deccan Herald, 8 April 2011.

34 ' $2 \mathrm{G}$ scam: Supreme Court upset with Khurshid's remarks, asks "Are we wasting our time?", 12 October 2011, at www.ndtv.com/article/india/2g-scam-supreme-court-upset-withkhurshid-s-remarksasks-are-we-wasting-our-time-140599, accessed 15 December 2011.

35 S Khilnani, The Idea of India, New Delhi: Penguin, 1999; and R Guha, India after Gandhi: The History of the World's Largest Democracy, Basingstoke: Pan Macmillan, 2007.

36 J Baudrillard, 'Simulacra and simulations', in M Poster (ed), Jean Baudrillard: Selected Writings, Stanford, CA: Stanford University Press, 1988, pp 166-184.

37 Mitchell, What do Pictures Want?, p 56.

\section{Notes on contributor}

Ravinder Kaur is Associate Professor and Director of the Centre for Global South Asian Studies, Department of Cross-cultural and Regional Studies, University of Copenhagen, Denmark. Her work includes Since 1947: Partition Narratives among Punjabi Migrants of Delhi (Oxford University Press, 2007); editor, Religion, Violence and Political Mobilisation in Contemporary South Asia (Sage Publications, 2005), as well as a number of articles and book chapters. She is currently responsible for a research programme funded by the Danish Social Sciences Research Council on the ongoing social-political transformations in post-reform India. 